\title{
Development of polyclonal antisera against movement proteins from three poleroviruses infecting cucurbits
}

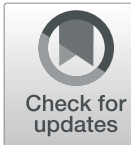

\author{
Shao-Kang Zhang ${ }^{1,2+}$, Tian-Yu Zhao ${ }^{1,2+}$, Xing Shi ${ }^{1,2+}$, Yu-Zi Liu ${ }^{1,2}$, Ying Wang ${ }^{1,2}$, Zong-Ying Zhang ${ }^{1,2}$, Da-Wei Li ${ }^{1,3}$,
} Jia-Lin Yu ${ }^{1,3}$, Qiao-Xia Shang ${ }^{4}$ and Cheng-Gui Han ${ }^{1,2^{*}}$ (D)

\begin{abstract}
Cucurbit aphid-borne yellows virus (CABYV), melon aphid-borne yellows virus (MABYV) and suakwa aphid-borne yellows virus (SABY) are three poleroviruses that infect cucurbit crops. Developing specific antisera against such viruses is crucial for their detection and functional understanding of related genes. However, no studies have yet reported viral detection using antisera against movement proteins (MP) in these three viruses. In this study, we generated plasmids expressing three viral MP genes, and transformed them into the Escherichia coli strain, Rosetta, to recombinantly express and purify fusion proteins. Then, polyclonal antisera were derived by immunizing New Zealand white rabbits, after which western blotting was used to determine the titer, sensitivity and specificity of the antisera. The antisera titers against MPCABV ${ }^{C} M^{M A B W}$ and $M^{S A B W}$ were 1:512000, 1:256000 and 1:256000, respectively. The optimized working concentrations for the three antisera ranged between 1:10000 and 1:64000. Additionally, antisera against MPCABW and MPMABW only reacted with their corresponding MP proteins. Antiserum against MP ${ }^{\mathrm{SABV}}$ not only had the strongest reaction with its MP, but also reacted weakly with MPCABV and MPMABYV. All three antisera exerted no serological reactions with other poleroviruses. Furthermore, our data showed that all antisera specifically detected MPs in both Nicotiana benthamiana and cucumber leaves. Thus, we have established a system that sensitively detects three poleroviruses infecting cucurbits, using antisera against MPs. We provide a foundation for future research on the serological detection of these viruses, and interaction mechanisms between viruses and host plants.
\end{abstract}

Keywords: Cucurbit aphid-borne yellows virus, Melon aphid-borne yellows virus, Suakwa aphid-borne yellows virus, Movement protein, Prokaryotic expression, Antiserum preparation, Virus detection

\section{Background}

Cucurbits are important fruit crops across the world. Plant viruses that infect cucurbits cause significant economic losses and limit cucurbits production (Gholamalizadeh et al. 2008; Knierim et al. 2014; Chikh-Ali et al. 2019). Cucurbit aphid-borne yellows virus (CABYV),

\footnotetext{
* Correspondence: hanchenggui@cau.edu.cn

†Shao-Kang Zhang, Tian-Yu Zhao and Xing Shi contributed equally to this work.

${ }^{1}$ Ministry of Agriculture Key Laboratory of Pest Monitoring and Green Management, and State Key Laboratory for Agro-biotechnology, China Agricultural University, Beijing 100193, People's Republic of China ${ }^{2}$ Department of Plant Pathology, College of Plant Protection, China Agricultural University, Beijing 100193, People's Republic of China Full list of author information is available at the end of the article
}

melon aphid-borne yellows virus (MABYV) and suakwa aphid-borne yellows virus (SABYV) are three important viruses infecting cucurbits, which belong to the Polerovirus genus, part of the Luteoviridae family (Lecoq et al. 1992; Xiang et al. 2008a; Shang et al. 2009). CABYV was first reported in France in 1992, where it infected cucurbit crops, and was later found in several other countries, including China (Lecoq et al. 1992; Lemaire et al. 1993; Abou-Jawdah et al. 1997; Juarez et al. 2004; Mnari Hattab et al. 2005; Tomassoli and Meneghini 2007; Xiang et al. 2008b; Bananej et al. 2009; Orfanidou et al. 2014). Interestingly, CABYV also naturally infects passion fruit and pepper, causing large yellow areas on leaves (Vidal

(c) The Author(s). 2020 Open Access This article is licensed under a Creative Commons Attribution 4.0 International License, which permits use, sharing, adaptation, distribution and reproduction in any medium or format, as long as you give appropriate credit to the original author(s) and the source, provide a link to the Creative Commons licence, and indicate if changes were made. The images or other third party material in this article are included in the article's Creative Commons licence, unless indicated otherwise in a credit line to the material. If material is not included in the article's Creative Commons licence and your intended use is not permitted by statutory regulation or exceeds the permitted use, you will need to obtain permission directly from the copyright holder. To view a copy of this licence, visit http://creativecommons.org/licenses/by/4.0/ 
et al. 2018; Liu et al. 2019; Zhang et al. 2019). MABYV and SABYV were first reported in China in 2008 and 2009, respectively (Xiang et al. 2008a; Shang et al. 2009). MABYV is widely distributed across several provinces in China and Thailand, however SABYV has only been detected in coastal provinces, such as Fujian and Guangdong, in southern China (Shang et al. 2009; Knierim et al. 2014). SABYV was also reported in several Southeast Asian countries, such as Thailand, the Philippines and East Timor (Knierim et al. 2010; Maina et al. 2016; Cheewachaiwit et al. 2017). All three viruses are limited to the phloem tissue of host plants and are transmitted by aphids in a persistent circulative and non-propagative manner (Hogenhout et al. 2008; Brault et al. 2010). These three viruses are highly specific to particular vectors and cannot be transmitted mechanically (Brault et al. 2010). The main symptoms of these viral diseases include yellowing and thickening of old leaves, which result in severe reductions in crop yield, however, all three viruses exert no significant effects on fruit quality and shape (Lecoq et al. 1992; Lemaire et al. 1993; Xiang et al. 2008a; Shang et al. 2009).

The poleroviruses virion, including CABYV, MABYV and SABYV, is a ball-shaped icosahedron with a diameter of $25-30 \mathrm{~nm}$, encapsulating the genome RNA. The virions are relatively stable and not sensitive to chloroform and non-ionic detergents, but are destroyed under high-salt conditions (D'Arcy and Domier 2005). The genome of all three viruses consists of a single positiveRNA strand, approximately 5674-5843 nucleotides in length. It contains seven open reading frames (ORFs) (Additional file 1: Figure S1). The first three ORFs are expressed from genomic RNA and the others are expressed from subgenomic RNA (Guilley et al. 1994; Smirnova et al. 2015). Specifically, the P0 protein encoded by ORF0 is a typical RNA silencing suppressor, which enhances viral pathogenicity, and promotes viral accumulation by interacting with host plant genes (Prufer et al. 2006; Han et al. 2010; Zhuo et al. 2014; Sun et al. 2018; Li et al. 2019; Rashid et al. 2019). The P1 protein encoded by ORF1 serves as a protease, helicase and viral genome-linked protein (VPg). A P1-P2 fusion protein encoded via a ribosomal frameshift event has replicase activity which regulates poleroviruses replication in hosts, and serves as a marker for viral detection and identification (D'Arcy and Domier 2005; Yahaya et al. 2019). The intergenic-non-coding region (intergenic-NCR) is approximately $80 \mathrm{nt}$ in length, and is located between ORF2 and ORF3a. The P3a protein which substitutes an AUG initiation codon with ACG is encoded by ORF3a and is indispensable for viral longdistance movement. When the conserved proline 18 in P3a has the non-synonymous substitution, viruses lose their systemic infection (Smirnova et al. 2015; Zhang et al. 2018). The coat protein (CP) is encoded by ORF3, which participates in virion assembly, long-distance movement, and aphid-mediated poleroviruses transmission (Ziegler-Graff et al. 1996; Lee et al. 2005; Hipper et al. 2014). The read-through protein, encoded by ORFs 3 and 5 , is closely related to aphid transmission, virion assembly, long-distance movement, phloem limited viral infection, and its $\alpha$-helix formed in the C-terminus is essential to systemic infection and symptom expression (Brault et al. 1995; Bruyère et al. 1997; Peter et al. 2009; Hipper et al. 2014; Xu et al. 2018). MP encoded by ORF4 was located in the plasmodesmata, mitochondria, and chloroplast, and is associated with viral replication, cell-to-cell movement and long-distance movement (Sokolova et al. 1997; Lee et al. 2002; Hipper et al. 2013; Chen et al. 2018; DeBlasio et al. 2018). However, the function of MP on longdistance movement remains unclear.

Currently, poleroviruses are detected mainly by using reverse transcription polymerase chain reaction (RT-PCR) (He et al. 2006; Knierim et al. 2010). Multiple RT-PCR was ever used to detect CABYV, MABYV, SABYV, and identify three distinct brassica yellow virus (BrYV) genotypes (Shang et al. 2012; Zhang et al. 2015). In terms of serological investigation of these three viruses, only antiserum against CABYV, prepared by purified virions, was used for western blotting or enzyme-linked immunosorbent assay (ELISA) (Lecoq et al. 1992), however, it is hard to purify virus particles due to its low accumulation in the host, and the virus detection result by the anti-CP antiserum may not prove whether the virus is in active or not. In contrast, the positive results of MP detection indicated that such viruses may be replicating in hosts (Yang et al. 2019). Recent studies have shown that some viruses from the Luteoviridae family, including barley yellow dwarf virus PAV (BYDVPAV) and potato leafroll virus (PLRV) can be detected by corresponding polyclonal antiserum against MPs (Chay et al. 1996; Yang et al. 2019; Hu et al. 2020). However, no studies have yet developed polyclonal antiserum against MPs of these three cucurbit-infecting viruses, or investigated their serological inter-relationships. In our work, to generate polyclonal antisera, His-MBP-MP purified fusion proteins, recombinantly produced in prokaryotic expression systems, were used to immunize New Zealand rabbits. Western blotting analysis showed that all viral MPs were specifically detected by their own antisera. We further confirmed serological relationships among them, and provide fundamental tools for future research on the serological detection of these viruses, and interactions between viruses and host plants.

\section{Results}

Prokaryotic MP expression, purification and production of antisera

$\mathrm{MP}^{\mathrm{CABYV}}, \mathrm{MP}^{\mathrm{MABYV}}$ and MP $\mathrm{MABYV}^{\mathrm{S}}$ genes were amplified by $\mathrm{PCR}$ and cloned into the prokaryotic expression 
vector $\mathrm{pDB}-\mathrm{His}-\mathrm{MBP}$, respectively. After that, the three recombinant vectors were individually transformed into the E. coli strain, Rosetta. Sodium dodecyl sulfate polyacrylamide gel electrophoresis (SDS-PAGE) analysis showed that a $65-\mathrm{kDa}$ band corresponding to His+ $\mathrm{MBP}+\mathrm{MP}$ was generated by all three recombinant proteins, indicating successful protein expression and purification. His-MBP-CABYV-MP fusion protein was eluted with $200 \mathrm{mM}$ and $500 \mathrm{mM}$ imidazole (Fig. 1a). HisMBP-MABYV-MP fusion protein was eluted with 100 $\mathrm{mM}$ and $200 \mathrm{mM}$ imidazole (Fig. 1b), and His-MBPSABYV-MP fusion protein was eluted with $80-200 \mathrm{mM}$ imidazole (Fig. 1c). Three mg of each concentrated protein was then subcutaneously injected into New Zealand white rabbits, and approximately $30 \mathrm{~mL}$ of each polyclonal antiserum was generated.

\section{Antisera titer analysis}

To determine the titer of three antisera we obtained, $\mathrm{MP}^{\mathrm{CABYV}}, \mathrm{MP}^{\mathrm{MABYV}}$, and $\mathrm{MP}^{\mathrm{SABYV}}$ genes were cloned into the transient expression vector, pMDC32, and then were individually delivered into $N$. benthamiana leaves via agro-infiltration method. Injection of the pMDC32 empty vector was used as a negative control. All three MPs were transiently expressed in $N$. benthamiana plants and their leaves were collected at 3 days post inoculation (dpi) with Agrobacterium suspension to extract total proteins. Western blotting results showed that all antisera detected their corresponding MPs. Furthermore, antiserum against MP ${ }^{\mathrm{CABYV}}$ detected MP $\mathrm{CABYV}^{\mathrm{s}}$ protein even when it was diluted to 1:512000 (Fig. 2a). However, antisera against $\mathrm{MP}^{\mathrm{MABYV}}$ and $\mathrm{MP}^{\mathrm{SABYV}}$ detected their corresponding proteins at 1:256000 dilution (Fig. 2b, c). From the perspective of color appearance and economics, the optimal working concentration of the three antisera ranged from 1:10000 to 1:64000.

\section{Antisera sensitivity analysis}

To analyze the sensitivity of three antisera, total proteins from $N$. benthamiana leaves expressing $\mathrm{MP}^{\mathrm{CABYV}}$, $\mathrm{MP}^{\mathrm{MABYV}}$, and $\mathrm{MP}^{\mathrm{SABYV}}$ were extracted respectively and serially diluted in equal proportions. Western blotting results showed that when antisera against $\mathrm{MP}^{\mathrm{CABYV}}$, $\mathrm{MP}^{\mathrm{MABYV}}$, and $\mathrm{MP}^{\mathrm{SABYV}}$ were diluted to $1: 1000$, they
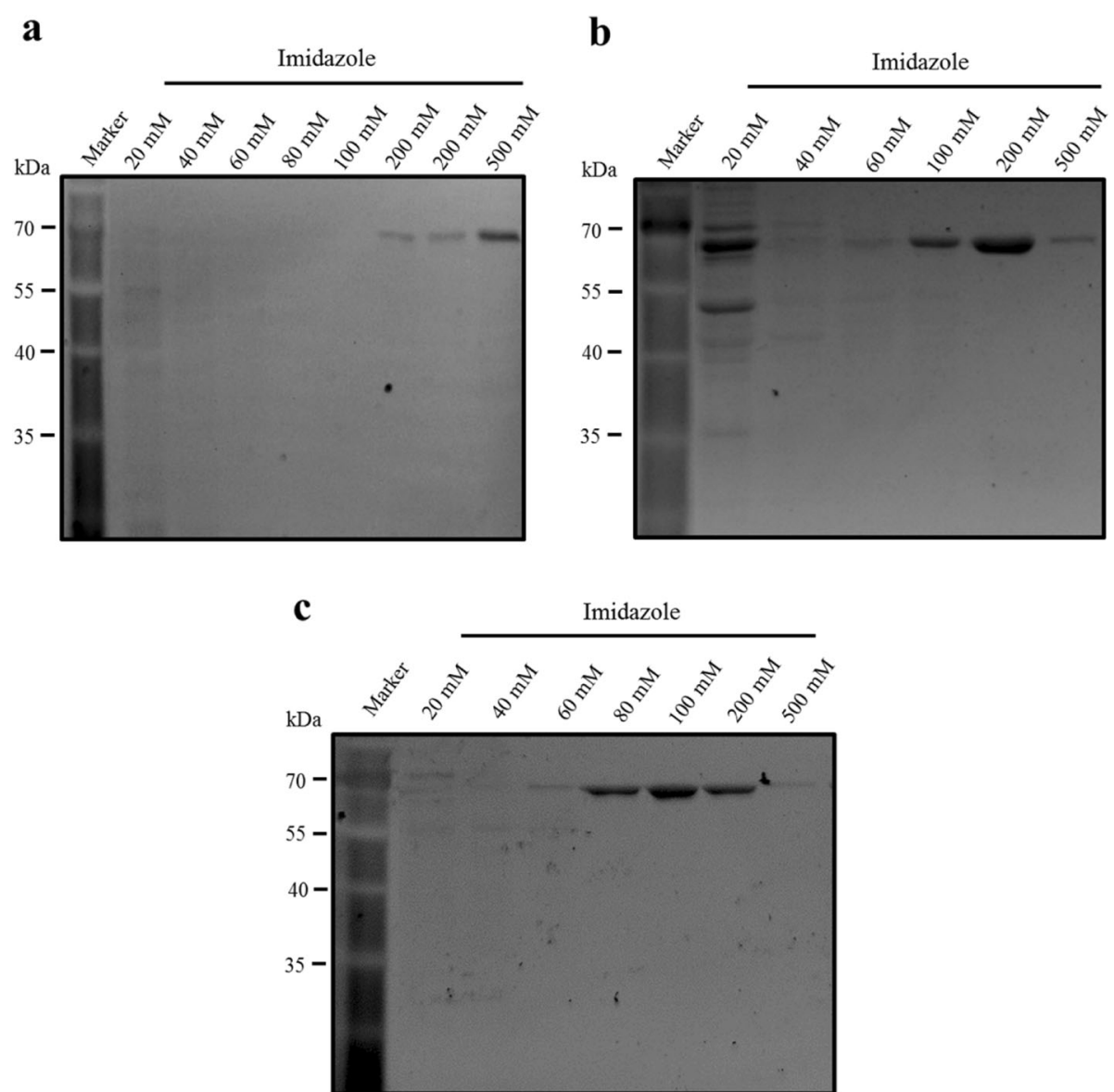

Fig. 1 SDS-PAGE analysis of CABYV-MP (a), MABYV-MP (b) and SABYV-MP (c) recombinant proteins. The first lane shows pageruler prestained protein ladder (Marker), and the other lanes are fusion proteins eluted with seven different concentrations of imidazole 


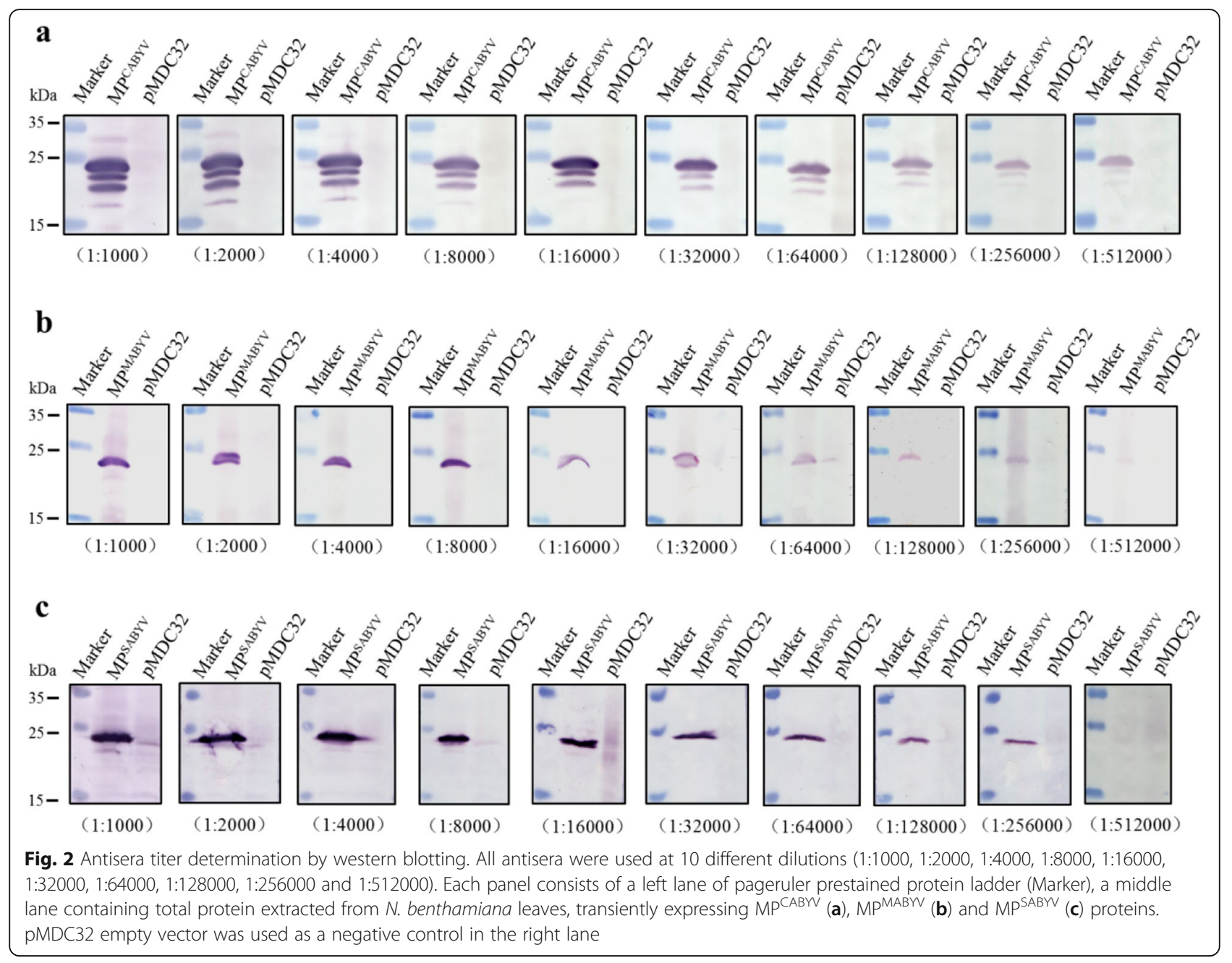

detected their corresponding protein samples diluted 128,64 , and 40 times, respectively. Subsequently, when these three antisera were diluted to $1: 10000$, they detected their protein samples diluted to 80,16 , and 16 times, respectively. When we diluted antisera to 1:20000, total protein samples corresponding to MP ${ }^{\mathrm{CABYV}}$ diluted to 32 times were still detectable, so antiserum against MPCABYV showed the highest sensitivity. In contrast, under the same conditions, antisera against $\mathrm{MP}^{\mathrm{MABYV}}$ and MP ${ }^{\mathrm{SABYV}}$ exhibited a lower sensitivity to their corresponding protein samples, and samples diluted to 8 times were detected (Fig. 3).

\section{Antisera specificity analysis}

Strong serological cross-reactions exist between different poleroviruses (D'Arcy and Domier 2005), therefore, it was necessary to determine whether antisera specifically detected target viruses. To analyze the specificity of three antisera, several MPs including MP ${ }^{\mathrm{CABYV}}, \mathrm{MP}^{\mathrm{MA}-}$ BYV, $\mathrm{MP}^{\mathrm{SABYV}}$, 3Flag-MP ${ }^{\mathrm{BrYV}}$, 3Flag-MP ${ }^{\mathrm{PLRV}}$ and 3Flag$\mathrm{MP}^{\mathrm{ScYLV}}$ (sugarcane yellow leaf virus) constructed in
pMDC vector were transiently expressed in $N$. benthamiana leaves via agro-infiltration. Injection of the pMDC32 empty vector was used as a negative control. Inoculated $N$. benthamiana leaves were collected at 3 dpi with Agrobacterium suspension to extract total proteins for western blotting analysis. All antisera were used at three dilutions (1:1000, 1:10000 and 1:20000). Antisera against MP $\mathrm{PABYV}^{\mathrm{C}}$ and MP $\mathrm{MABYV}^{\mathrm{M}}$ only consistently detected their corresponding MPs in total protein samples, regardless of the dilution level of antisera, indicating that these two antisera had a high specificity towards their target proteins (Fig. 4a, b). In the case of antiserum against $\mathrm{MP}^{\mathrm{SABYV}}$, it had the strongest reaction with $\mathrm{MP}^{\mathrm{SABYV}}$ at all three dilution levels, and it also reacted with $\mathrm{MP}^{\mathrm{CABYV}}$ and $\mathrm{MP}^{\mathrm{MABYV}}$ at a weaker level. This meant that antiserum against $\mathrm{MP}^{\mathrm{SABYV}}$ could specifically detect three different poleroviruses infecting cucurbits (Fig. 4c). Furthermore, all three antisera had no serological cross-reactivity with other MPs from the same genus, including $\mathrm{MP}^{\mathrm{PLRV}}, \mathrm{MP}^{\mathrm{BrYV}}$ and $\mathrm{MP}^{\mathrm{ScYLV}}$. 


\section{a}

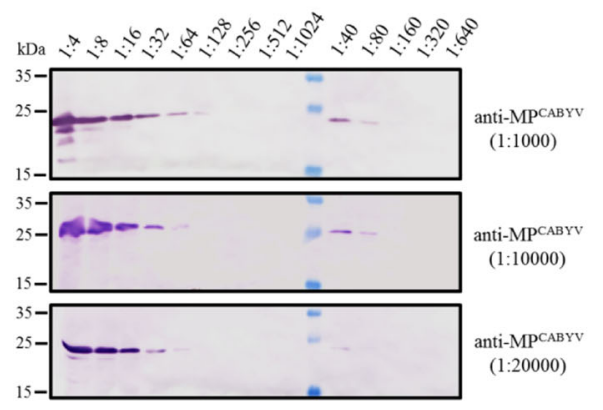

b

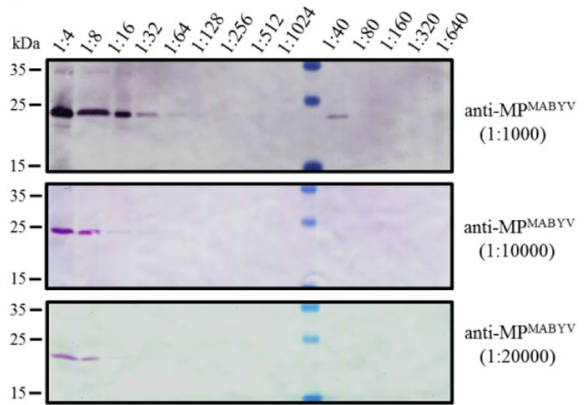

c

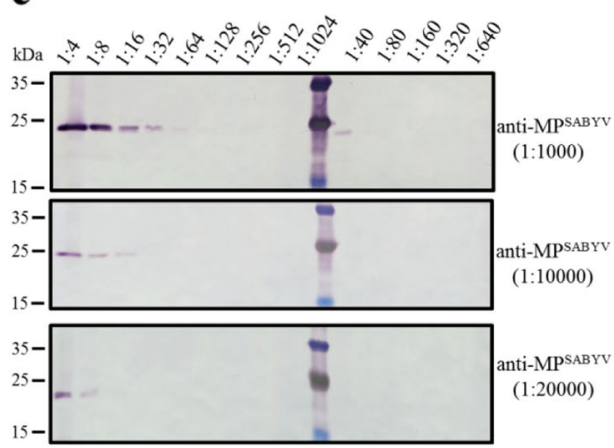

Fig. 3 Sensitivity analysis of antisera by western blotting. Marker: pageruler prestained protein ladder. The remaining lanes show several different dilutions of protein samples extracted from $N$. benthamiana leaves $(1: 4,1: 8,1: 16,1: 32,1: 64,1: 128,1: 256,1: 512,1: 1024$ and 1:40, 1:80, 1:160, 1:320, 1:640). Anti-MP ${ }^{\mathrm{CABYV}}(\mathbf{a})$, anti-MPPABYV $(\mathbf{b})$ and anti-MP ${ }^{\mathrm{SABVV}}$ (c) were used at 1:1000, 1:10000 and 1:20000, respectively

\section{Application of antisera to viral detection}

CABYV and MABYV full-length infectious clones were inoculated into $N$. benthamiana leaves, via agroinfiltration (Prufer et al. 1995; Xiang 2011). Inoculated leaves were harvested at 3 dpi to extract total proteins for further western blotting analysis. Our data showed that antisera specifically detected CABYV and MABYV in $N$. benthamiana leaves, which agreed with RT-PCR detection results (Fig. 5a, b), indicating that our antisera were suitable for detecting viruses in a model plant, $N$. benthamiana.

Simulation detections were conducted to test whether antisera detected MPs in natural hosts of these viruses, such as cucumbers, due to a lack of available natural cucurbits samples infected by these three viruses. Diluted protein-containing transiently expressed MPs in $N$. benthamiana leaves were mixed with healthy cucumber leaf extracts. Western blotting results showed that protein samples diluted 256, 64 and 128 times were specifically detected by antisera against $\mathrm{MP}^{\mathrm{CABYV}}, \mathrm{MP}^{\mathrm{MABYV}}$ and $\mathrm{MP}^{\mathrm{SABYV}}$, respectively (Fig. $5 \mathrm{c}$ ). Total proteins from healthy cucumber leaves exerted no serological reactions with these three antisera, and no interference was observed with specific serological responses of the three antisera to their corresponding MP proteins.

\section{Discussion}

Virus infection depends on its efficient movement in hosts. Blocking virus movement provides strategies for host plants to defend against harmful viruses, therefore it is important to study how MPs participate in virus movement in hosts. MPs play essential roles in virus infection. They not only promote intercellular movement and systemic viral movement but also serve as critical pathogenic factors, causing purple symptoms in infected leaves (Chen et al. 2018). Thus, we established a specific viral detection system by developing antisera against three different MPs. Such efforts are indispensable for studying viral occurrence and distribution, potentially revealing MP functions at the protein level.

Antisera against $\mathrm{MP}^{\mathrm{CABYV}}$ and $\mathrm{MP}^{\mathrm{MABYV}}$ showed higher protein specificities, as they reacted only with their homologous proteins, whereas antiserum against $\mathrm{MP}^{\mathrm{SABYV}}$ reacted with all three viral proteins. Interestingly, we distinguished three different viruses by the strength of the serological response under these conditions; the strongest response was $\mathrm{MP}^{\mathrm{SABYV}}$, followed by $\mathrm{MP}^{\mathrm{MABYV}}$, and the weakest response was MP ${ }^{\mathrm{CABYV}}$ (Fig. 4c). $M P^{\mathrm{CABYV}}, \mathrm{MP}^{\mathrm{MABYV}}$ and $M \mathrm{P}^{\mathrm{SABYV}}$ share a high degree of homology. At the nucleotide level, MP ${ }^{\mathrm{SABYV}}$ shares approximately $79.7 \%$ identity with $\mathrm{MP}^{\mathrm{CABYV}}$, and $88.5 \%$ identity with $\mathrm{MP}^{\mathrm{MABYV}}$. At the amino acid level, 

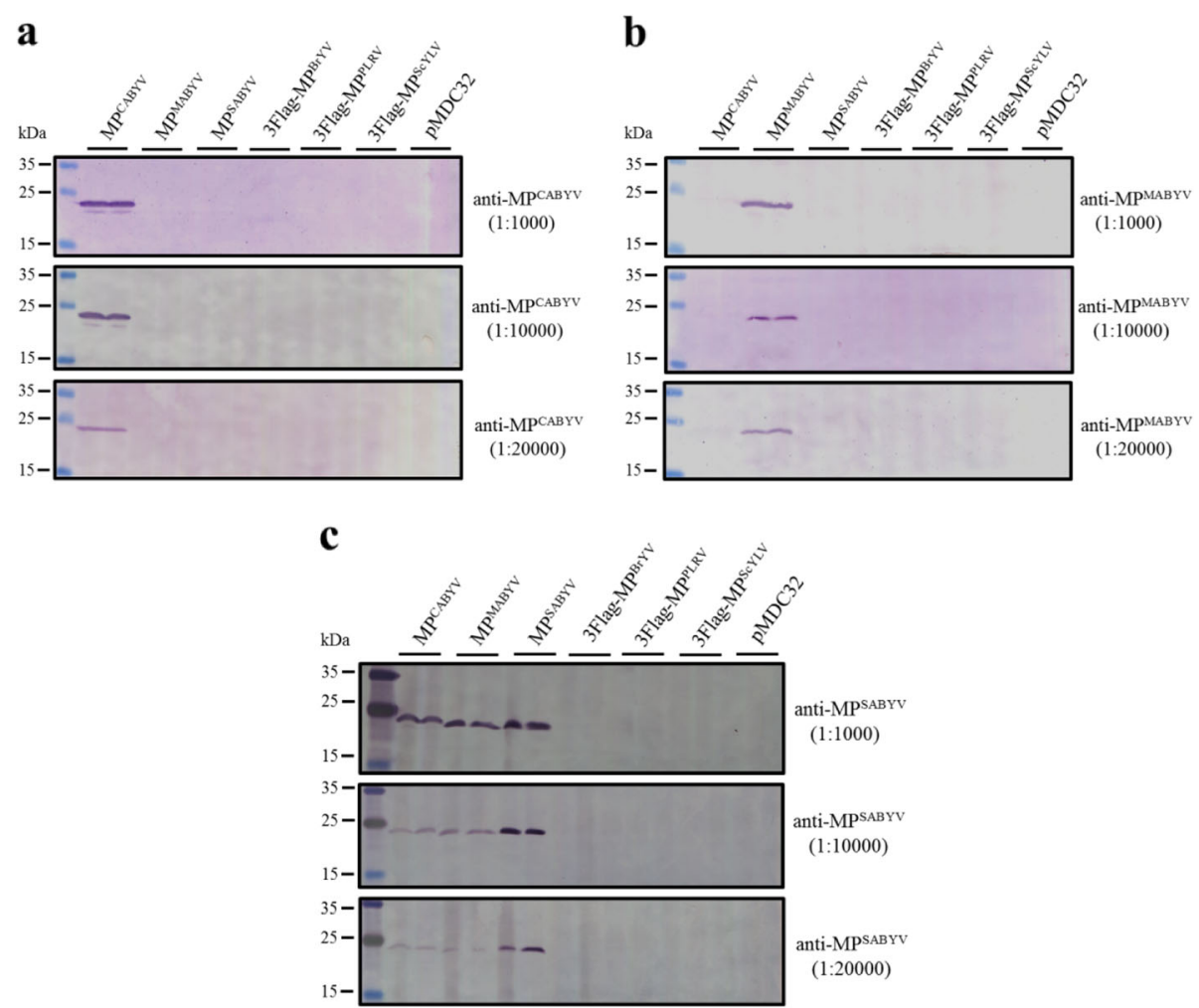

Fig. 4 Specificity analysis of antisera by western blotting. The left lane is the pageruler prestained protein ladder marker, and the other lanes are proteins extracted from $N$. benthamiana leaves, transiently expressing different MPs including CABVV, MABV, SABVV, BrY, PLRV and ScYLV. pMDC32 empty vector is a negative control. The three test antisera, anti-MPCABW $(\mathbf{a})$, anti-MPMABW $(\mathbf{b})$ and anti-MPSABV $(\mathbf{c})$ were used at 1:1000, 1:10000 and 1:20000

$\mathrm{MP}^{\mathrm{SABYV}}$ shares only $65.4 \%$ identity with $\mathrm{MP}^{\mathrm{CABYV}}$ and $75.1 \%$ identity with $\mathrm{MP}^{\mathrm{MABYV}}$, which is positively correlated with the strength of the serological response. However, we could not distinguish among these three viruses under the condition of low SABYV titer, and this issue should be addressed in the future research.

Cucurbit crops such as cucumber, watermelon, melon, and pumpkin are natural hosts of CABYV, MABYV and SABYV. The antisera we developed are not only ideal for MP detection in $N$. benthamiana, but also in natural hosts. The simulated detection results suggested that total proteins from cucumber did not interfere with the specific reactions between antisera and their corresponding MPs (Fig. 5). Equally, CABYV was detected in the natural host, passion fruit, by our antiserum against $\mathrm{MP}^{\mathrm{CABYV}}$, providing new evidence for the application of our antiserum in the field (Zhang et al. 2019). Our work shows that all antisera have a wide range of applications, although detection in cucurbits requires further verification.

It was reported that antiserum developed based on the MP from BYDV-PAV Qinghai isolate not only reacted with PAV105 isolate sharing $79.3 \%$ identity in amino acid, but also had strong serological cross-reactivity with the other BYDV MPs sharing 62.7-83.3\% identity in amino acid ( $\mathrm{Hu}$ et al. 2020), indicating that serological cross-reactions exiseted between MPs with high homology. Previous studies showed that besides CABYV, MABYV, and SABYV, several other poleroviruses were also found infecting cucurbit crops, including luffa aphid-borne yellows virus (LABYV), pepo aphid-borne yellows virus (PABYV), and cucumber aphidborne yellows virus (CuABYV) (Knierim et al. 2015). Additionally, zucchini aphid-borne yellows virus (ZABYV) was reported as a new virus in China in 2019 (Peng et al. 2019). MPs from these viruses share approximately $23.08-75.92 \%$ amino acid identity with MPs from CABYV, MABYV, and SABYV (Table 1), of which PABYV-MP showed the highest identity, and LABYV-MP showed the lowest identity. Further studies are required to investigate serological relationships among MPs of all these viruses.

\section{Conclusions}

CABYV, MABYV and SABYV are important viruses infecting cucurbit crops. The development of specific antisera is essential for virus detection, and exploring viral replication, movement and interaction with host plants. In our study, we expressed and purified three MPs using a prokaryotic expression system, and developed their polyclonal antisera of high titer, sensitivity and specificity, although antiserum against $\mathrm{MP}^{\mathrm{SABYV}}$ had a relatively weaker reaction to MP ${ }^{\mathrm{CABYV}}$ and $\mathrm{MP}^{\mathrm{MABYV}}$. The system 
$\mathbf{a}$

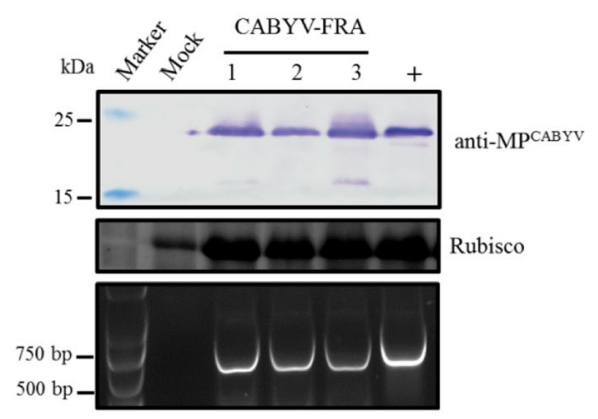

b

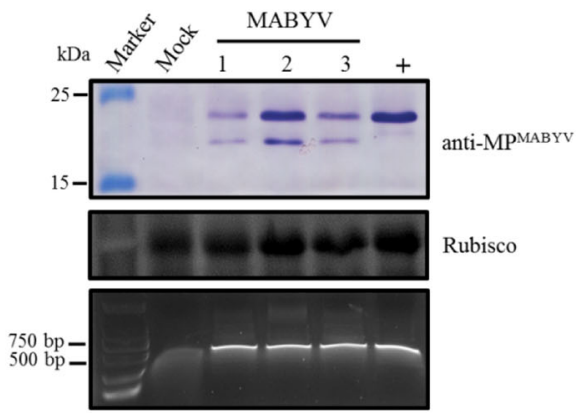

c

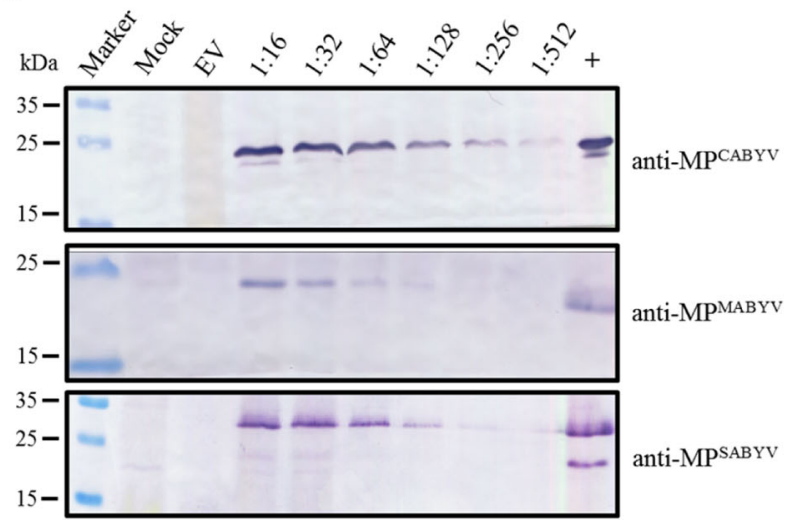

Fig. 5 Application analysis of antisera by western blotting. $\mathbf{a}, \mathbf{b}$ Expression comparisons of CABV and MABV in N. benthamiana leaves inoculated with full-length infectious clones by western blotting and RT-PCR. Marker: pageruler prestained protein ladder; Mock: inoculated pCassRZ empty vector; Lanes 1, 2, 3: leaf samples expressing CABVV or MABYV infectious clone; "+": proteins extracted from N. benthamiana leaves transiently expressing MPCABYV or MPMABV . Rubisco stained with coomassie brilliant blue is used as a loading control (middle panel). The lower panels are RT-PCR data from the same samples. c Simulation detection of cucumber samples infected with CABYV, MABYV or SABYV. Marker: pageruler prestained protein ladder; Mock: proteins extracted from healthy cucumber leaves; EV: N. benthamiana leaves inoculated with pMDC32 empty vector; " + ": protein extracted from $N$. benthamiana leaves transiently expressing the three MP genes; The other lanes show different dilutions of proteins extracted from $N$. benthamiana leaves transiently expressing MPs (1:16, 1:32, 1:64, 1:128, 1:256 and 1:512) and mixed with proteins extracted from healthy cucumber leaves. The three antisera were used at 1:10000

we established can be successfully used for virus serological detection, and the investigation of interactions between viruses and host plants.

\section{Methods}

\section{Plant materials and growth conditions}

$N$. benthamiana seeds were donated by Prof. David Baulcombe (Department of Plant Sciences, University of

Table 1 Comparison of MP amino acid sequence identity (\%) between CABYV, MABYV, SABYV and other poleroviruses infecting cucurbits

\begin{tabular}{lllll}
\hline Poleroviruses & Accession uumber & CABY & MABYV & SABYV \\
\hline LABYV & NC_027703 & 24.27 & 26.83 & 23.08 \\
PABYV & NC_030225 & 75.92 & $70 . .31$ & 71.88 \\
CuABYV & FJ460218 & 59.28 & 59.28 & 60.31 \\
ZABYV & MK050791 & 56.48 & 55.44 & 55.96 \\
\hline
\end{tabular}

Cambridge, UK), and were propagated and preserved in our laboratory. $N$. benthamiana plants were grown at $24 \pm 1{ }^{\circ} \mathrm{C}$ and a relative humidity of $40 \%$, with a 16 -h light /8-h dark cycle.

\section{Vector construction}

Full-length MP $\mathrm{CABYV}^{\mathrm{CAccession}} \mathrm{No}$ : EU000535), MP $\mathrm{MA}^{\mathrm{MA}}$ BYV (Accession No: EU000534), and MP SABYV $^{\text {Acces- }}$ sion No: NC_018571.2) genes were amplified by PCR using forward and reverse primers (Additional file 2: Table S1). The full-length cDNA clones pCaCABYV65 and pCaMABYV36 used as templates were constructed in our laboratory (Xiang 2011). The plasmid pMD19SABYV containing ORF4 used as the template was synthesized by a biotech company (Tsingke biological technology, China). PCR was performed using Primer Star Max HS DNA Polymerase (TaKaRa, Japan) as previously described with slight modifcations (Zhang et al. 2015). 
PCR products were electrophoresed on a $1 \%$ agarose gel, excised, purified and ligated into the prokaryotic expression vector pDB-His-MBP (DNASU Plasmid Repository, Arizona, USA), pre-digested with the restriction enzymes, NdeI and $\mathrm{XhoI}$ at $37^{\circ} \mathrm{C}$ for $4 \mathrm{~h}$. Histidine and MBP tags can increase protein solubility with no discernible effects on antigenic determinants of the recombinant protein. The ligation products were transformed into the E.coli strain, MC1022 to obtain the positive clones and extracted plasmids. The correctness of the extracted plasmids was verified by sequencing analysis (Tsingke biological technology, China). Transient expression vector $\mathrm{pMDC} 32-\mathrm{MP}^{\mathrm{CABYV}}$, $\mathrm{pMDC} 32-\mathrm{MP}^{\mathrm{MABYV}}$ and pMDC32-MP ${ }^{\mathrm{SABYV}}$ were constructed using the same methods (Curtis and Grossniklaus 2003).

\section{Agrobacterium-mediated transformation}

The freezing-thawing method with liquid nitrogen was used to transform the transient expression vectors into competent cells of Agrobacterium tumefaciens strain, GV3101 (Holsters et al. 1978). Approximately 3-5 $\mu \mathrm{L}$ plasmid was added to $100 \mu \mathrm{L}$ of competent cells, gently mixed and incubated on ice for $30 \mathrm{~min}$, and then frozen in liquid nitrogen for $1 \mathrm{~min}$. The mix was melted at $37^{\circ} \mathrm{C}$ for $5 \mathrm{~min}$, after which $400 \mu \mathrm{L}$ of LB liquid medium was added. After $4 \mathrm{~h}$ resuscitative mixing at $28^{\circ} \mathrm{C}$, the mix was spread onto LB plates supplemented with Kanamycin $(50 \mathrm{mg} / \mathrm{mL})$ and Rifampicin $(50 \mathrm{mg} / \mathrm{mL})$ and incubated at $28^{\circ} \mathrm{C}$ for $48 \mathrm{~h}$.

The agro-infiltration assays were performed as previously described (Zhuo et al. 2014; Zhang et al. 2018). A. tumefaciens strain GV3101 culture containing relevant vectors were individually incubated at $28^{\circ} \mathrm{C}$ for $16 \mathrm{~h}$, and mixed and injected into leaves of six-week-old $N$. benthamiana plants. All experiments shown in the results were repeated three times.

\section{Recombinant protein purification and generation of polyclonal antisera}

Three prokaryotic expression vectors carrying MPs, PDB-MPCABYV, PDB-MP ${ }^{\mathrm{MABYV}}$ and PDB-MP ${ }^{\mathrm{SABYV}}$, were individually transformed into the E.coli strain, Rosseta. Positive colonies were incubated overnight at $37^{\circ} \mathrm{C}$ with shaking at $220 \mathrm{rpm}$ in $10 \mathrm{~mL}$ of LB liquid medium containing kanamycin $(50 \mathrm{mg} / \mathrm{mL})$ and chloramphenicol (34 $\mathrm{mg} / \mathrm{mL}$ ), which were transferred to $1 \mathrm{~L}$ of $\mathrm{LB}$ liquid medium supplemented with kanamycin and chloramphenicol, and incubated at $37^{\circ} \mathrm{C}$ with shaking for $4-6 \mathrm{~h}$ to generate an $\mathrm{OD}_{600}$ between 0.6 and 0.8. Then, clutures were induced by $0.1 \mathrm{mM}$ isopropyl- $\beta$-D-thiogalactoside (IPTG; Sigma-Aldrich, St. Louis, MO, USA) at $18{ }^{\circ} \mathrm{C}$, and $180 \mathrm{rpm}$ for $18 \mathrm{~h}$. After that, bacteria were collected by centrifugation at $5000 \mathrm{rpm}$ for $6 \mathrm{~min}$. After ultrasonic disruption, supernatants were collected by centrifugation at $16000 \mathrm{rpm}$ for $40 \mathrm{~min}$. Clarified supernatants were added to a nickel-affinity column (Qiagen, Hilden, Germany), and proteins were washed by different concentrations $(20,40,60,80,100,200$, and 500 $\mathrm{mM}$ ) of imidazole eluent. Each elution fraction was subjected to SDS-PAGE to assess MP expression. The fraction containing MP was concentrated to generate purified fusion protein. The molecular weights of three recombinant proteins were predicted by SnapGene Viewer software (SnapGene, USA).

New Zealand white rabbits were injected with $400 \mu \mathrm{g}$ purified protein. After 2 weeks, rabbits were further given three consecutive enhanced immunizations (200 $\mu \mathrm{g}$ purified proteins), each 10 days apart. When immunizations were completed, positive blood was taken from the carotid artery, after which it was centrifuged twice at $5000 \mathrm{rpm}$ for $10 \mathrm{~min}$. From this, $30 \mathrm{~mL}$ polyclonal antisera against $\mathrm{MP}^{\mathrm{CABYV}}, \mathrm{MP}^{\mathrm{MABYV}}$ and $\mathrm{MP}^{\mathrm{SA}-}$ ${ }^{B Y V}$ were obtained (Beijing Protein Innovation Co. Ltd. conducted the rabbit immunization).

\section{Protein extraction and western blotting}

Protein extraction and western blotting were performed as described previously (Zhuo et al. 2014; Li et al. 2019). $0.1 \mathrm{~g} N$. benthamiana leaf samples were ground into powder in liquid nitrogen and then added with $300 \mu \mathrm{L}$ of $2 \times$ SDS buffer (100 mM Tris (pH 6.8), 20\% glycerol, $4 \%$ SDS, and $0.2 \%$ bromophenol blue) containing $10 \% \beta$ mercaptoethanol. Each sample was used after heating at $100{ }^{\circ} \mathrm{C}$ for $10 \mathrm{~min}$.

Proteins were separated by SDS-PAGE, and then transferred to nitrocellulose membranes (GE Healthcare, Buckinghamshire, UK) by electro-transfer (200 mA, 100 min). Membranes were blocked in $1 \times$ TBST buffer $(20$ $\mathrm{mM}$ Tris- $\mathrm{HCl}, 150 \mathrm{mM} \mathrm{NaCl}, 0.05 \%$ Tween-20, $\mathrm{pH}=8$ ), containing $5 \%$ milk at $37^{\circ} \mathrm{C}$ for $1 \mathrm{~h}$, followed by incubation with polyclonal antisera against $\mathrm{MP}^{\mathrm{CABYV}}, \mathrm{MP}^{\mathrm{MA}-}$ ${ }_{B Y V}$ and MP ${ }^{\text {SABYV }}$ respectively at $37^{\circ} \mathrm{C}$ for $1 \mathrm{~h}$. Subsequently, membranes were washed three times in $1 \times$ TBST, incubated with alkaline phosphatase (AP)-labeled goat anti-rabbit IgG secondary antibody (1:20000, Easybio, China) at $37^{\circ} \mathrm{C}$ for $1 \mathrm{~h}$, and followed by washing three times in $1 \times \mathrm{TBST}$. Then, membranes were incubated with buffer containing nitro-blue tetrazolium chloride (NBT) $(330 \mu \mathrm{g} / \mathrm{mL})$ and 5-Bromo-4-chloro-3indolyl phosphate p-toluidine salt (BCIP) $(165 \mu \mathrm{g} / \mathrm{mL})$ to reveal protein bands. The marker was pageruler prestained protein ladder (Thermo, USA). Coomassie brilliant blue R250 was used to stain the gel to indicate equal loading (Bio-rad, USA).

\section{Antisera titer determination}

pMDC32-MP ${ }^{C A B Y V}$, pMDC32-MP ${ }^{\mathrm{MABYV}}$ and pMDC32$\mathrm{MP}^{\mathrm{SABYV}}\left(\mathrm{OD}_{600}=0.5\right)$ were co-expressed with $\mathrm{P} 19$ 
$\left(\mathrm{OD}_{600}=0.2\right)$ in six-week-old $N$. benthamiana plants. Injection of the pMDC32 empty vector served as a negative control. P19 is a typical viral suppressor of RNA silencing (VSR) from tomato bushy stunt virus (TBSV) and the transient expression vector pGDP $19^{\mathrm{TBSV}}$ was provided by Prof. Andrew O. Jackson, University of California Berkeley (Bragg and Jackson 2004). Inoculated leaves were collected at $3 \mathrm{dpi}$ for protein extraction. All three antisera were equally diluted 1:1000, 1:2000, 1 : 4000, 1:8000, 1:16000, 1:32000, 1:64000, 1:128000, 1: 256000 and 1:512000 for western blotting to determine titers and optimal working concentrations.

\section{Antisera sensitivity analysis}

pMDC32-MP ${ }^{C A B Y V}$, pMDC32-MP ${ }^{\mathrm{MABYV}}$ and pMDC32$\mathrm{MP}^{\mathrm{SABYV}}\left(\mathrm{OD}_{600}=0.5\right)$ were co-expressed with TBSV P19 $\left(\mathrm{OD}_{600}=0.2\right)$ in six-week-old $N$. benthamiana plants. The pMDC32 empty vector served as a negative control. Inoculated leaves were collected at $3 \mathrm{dpi}$ to extract total proteins. Approximately $0.1 \mathrm{~g} N$. benthamiana leaves were used to generate protein samples by adding $300 \mu \mathrm{L} 2 \times$ sodium dodecyl sulfate (SDS) buffer. Samples were diluted by two gradients $(1: 4,1: 8,1: 16,1: 32,1: 64$, 1:128, 1:256, 1:512, 1:1024 and 1:40, 1:80, 1:160, 1:320, 1 : 640) for western blotting. Equally, all three antisera were diluted to 1:1000, 1:10000, and 1:20000.

\section{Antisera specificity analysis}

MP ${ }^{C A B Y V}$, MP $P^{M A B Y V}, M P^{S A B Y V}$, 3Flag-MP ${ }^{\text {BrYV }}$, 3Flag$\mathrm{MP}^{\mathrm{PLRV}}$ and 3 Flag-MP $\mathrm{ScYLV}^{\mathrm{ScY}}\left(\mathrm{OD}_{600}=0.5\right)$ were coexpressed with TBSV P19 $\left(\mathrm{OD}_{600}=0.2\right)$ in six-week-old $N$. benthamiana plants. The pMDC32 empty vector served as a negative control (The three transient expression vectors, 3Flag-MP ${ }^{\mathrm{BrYV}}$, 3Flag-MP ${ }^{\text {PLRV }}$ and 3Flag$\mathrm{MP}^{\mathrm{ScYLV}}$ were provided by Deng-Pan Zuo in our laboratory). Inoculated leaves were collected at $3 \mathrm{dpi}$ for total protein extraction. Western blotting was performed to assess antisera specificity. All three antisera were diluted to $1: 1000,1: 10000$ and $1: 20000$.

\section{Detection of $N$. benthamiana inoculated with full-length infectious clones}

We inoculated six-week-old $N$. benthamiana plants with full-length infectious CABYV and MABYV clones (Prufer et al. 1995; Xiang 2011). Injection of the transient expression vectors pMDC32-MPCABYV and pMDC32$\mathrm{MP}^{\mathrm{MABYV}}$ served as positive controls and the pCass-RZ empty vector served as a negative control. Inoculated leaves were harvested at $3 \mathrm{dpi}$. Western blotting was performed using antisera at 1:10000, which was compared with the RT-PCR detection results of the same samples. RT-PCR was performed as previously described (Chen et al. 2018).

\section{Simulation detection of natural host plants infected with virus}

Total proteins from six-week-old $N$. benthamiana leaves, expressing $\mathrm{MP}^{\mathrm{CABYV}}, \mathrm{MP}^{\mathrm{MABYV}}$ and $\mathrm{MP}^{\mathrm{SABYV}}$ were extracted. The protein from healthy cucumber leaves was extracted using the same method. Then, cucumber protein and each MP protein were mixed separately in equal volume, which was equally diluted at 1:16, 1:32, 1:64, 1: 128, 1:256 and 1:512. The pMDC32 empty vector, and cucumber protein served as negative controls. $N$. benthamiana leaves expressing MPCABYV, $\mathrm{MP}^{\mathrm{MABYV}}$ and $\mathrm{MP}^{\mathrm{SABYV}}$ served as positive controls. Western blotting was then conducted using antisera at 1:10000 to observe the serological reactions of CABYV, MABYV and SABYV in cucumber.

\section{Supplementary information}

Supplementary information accompanies this paper at https://doi.org/10. 1186/s42483-020-00065-8.

Additional file 1: Figure S1. Schematic representation of the CABYVCN genome. CABYV-CN is a positive-sense single-stranded RNA virus containing 5682 nucleotides, with seven ORFs encoding seven proteins. A small VPg is covalently bound to the $5^{\prime}$ end of the genomic RNA and there is neither a $3^{\prime}$-terminal poly (A) tail nor a tRNA-like structure in its RNA. ORF4 is $576 \mathrm{bp}(3539-4114 \mathrm{nt})$ in length, and its MP is expressed by subgenomic RNA.

Additional file 2: Table S1. Primers used for vector construction.

\section{Abbreviations}

BrYV: Brassica yellow virus; CABYV: Cucurbit aphid-borne yellows virus; CP: Coat protein; CuABYV: Cucumber aphid-borne yellows virus; dpi: Days post inoculation; ELISA: Enzyme-linked immunosorbent assay; IPTG: Isopropyl- $\beta$-D-thiogalactoside; LABYV: Luffa aphid-borne yellows virus; MABY: Melon aphid-borne yellows virus; MP: Movement protein; ORF: Open reading frame; PABYV: Pepo aphid-borne yellows virus; PLRV: Potato leafroll virus; RT-PCR: Reverse transcription polymerase chain reaction;

SABYV: Suakwa aphid-borne yellows virus; SCYLV: Sugarcane yellow leaf virus; SDS-PAGE: Sodium dodecyl sulfate polyacrylamide gel electrophoresis; TBST: Tris-buffered saline; TBSV: Tomato bushy stunt virus; VPg: Viral genomelinked protein; VSR: Viral suppressors of RNA silencing; ZABYV: Zucchini aphid-borne yellows virus

\section{Acknowledgments}

We thank Prof. Xian-Bing Wang and Prof. Yong-Liang Zhang, and other lab members for their constructive suggestions. We also thank Dr. Salah Bouzoubaa (University of Strasbourg, France) for providing the E. coli strain MC1022, thank Dr. Yuan-Yuan Li for providing the schematic representation of the genome of BrY, and thank Deng-Pan Zuo for providing the transient expression vectors including 3Flag-MP ${ }^{B r V}$, 3Flag-MP PLRV and 3Flag-MP ${ }^{\text {SCYLV }}$. We are grateful to Nitesh Datt for the revision of the manuscript and Zhi-Tong Zhang for the cultivation of Nicotiana benthamiana plants.

\section{Authors' contributions}

CGH conceived the study and revised the manuscript critically. SKZ, XS and YZL designed and carried out the experiments. SKZ and TYZ drafted the manuscript. YW, ZYZ, DWL, JLY and QXS contributed reagents/materials/ analysis tools. All authors read and approved the final manuscript.

\section{Funding}

This work was partly supported by the National Natural Science Foundation of China (31671995 and 31000840). 


\section{Availability of data and materials}

Not applicable.

\section{Ethics approval and consent to participate}

Not applicable.

\section{Consent for publication}

Not applicable.

\section{Competing interests}

The authors declare that they have no competing interests.

\section{Author details}

${ }^{1}$ Ministry of Agriculture Key Laboratory of Pest Monitoring and Green Management, and State Key Laboratory for Agro-biotechnology, China Agricultural University, Beijing 100193, People's Republic of China. 2Department of Plant Pathology, College of Plant Protection, China Agricultural University, Beijing 100193, People's Republic of China. ${ }^{3}$ Department of Microbiology \& Immunology, College of Biological Sciences, China Agricultural University, Beijing 100193, People's Republic of China. ${ }^{4}$ Beijing Key Laboratory of New Technology in Agricultural Application, College of Plant Science and Technology, Beijing University of Agriculture, Beijing 102206, People's Republic of China.

\section{Received: 23 April 2020 Accepted: 31 July 2020}

Published online: 02 September 2020

\section{References}

Abou-Jawdah Y, Sobb H, Fayyad A. First report of cucurbit aphid-borne yellows luteovirus in Lebanon. Plant Dis. 1997:81:1331.

Bananej K, Vahdat A, Predajna L, Glasa M. Molecular characterization of geographically different cucurbit aphid-borne yellows virus isolates. Acta Virol. 2009;53:61-4.

Bragg JN, Jackson AO. The C-terminal region of the barley stripe mosaic virus gammab protein participates in homologous interactions and is required for suppression of RNA silencing. Mol Plant Pathol. 2004;5:465-81.

Brault V, Uzest M, Monsion B, Jacquot E, Blanc S. Aphids as transport devices for plant viruses. C R Biol. 2010;333:524-38.

Brault V, Van den Heuvel JFJM, Verbeek M, Ziegler-Graff V, Reutenauer A, Herrbach $E$, et al. Aphid transmission of beet western yellows luteovirus requires the minor capsid read-through protein P74. EMBO J. 1995;14:650-9.

Bruyère A, Brault V, Ziegler-Graff V, Simonis MT, Van den Heuvel JFJM, Richards K, et al. Effects of mutations in the beet western yellows virus readthrough protein on its expression and packaging and on virus accumulation, symptoms, and aphid transmission. Virology. 1997;230:323-34.

Chay CA, Gunasinge UB, Dinesh-Kumar SP, Miller WA, Gray SM. Aphid transmission and systemic plant infection determinants of barley yellow dwarf luteovirus-PAV are contained in the coat protein readthrough domain and 17-kDa protein, respectively. Virology. 1996;219:57-65.

Cheewachaiwit S, Warin N, Phuangrat B, Rukpratanporn S, Gajanandana O, Balatero $\mathrm{CH}$, et al. Incidence and molecular diversity of poleroviruses infecting cucurbit crops and weed plants in Thailand. Arch Virol. 2017;162: 2083-90.

Chen $X R$, Wang $Y$, Zhao HH, Zhang XY, Wang XB, Li DW, et al. Brassica yellows virus' movement protein upregulates anthocyanin accumulation, leading to the development of purple leaf symptoms on Arabidopsis thaliana. Sci Rep. 2018;8:16273

Chikh-Ali M, Natsuaki T, Karasev AV. Molecular diversity of main cucurbit viruses in Syria. J Plant Pathol. 2019;101:1067-75.

Curtis MD, Grossniklaus U. A gateway cloning vector set for high-throughput functional analysis of genes in planta. Plant Physiol. 2003;133:462-9.

D'Arcy CJ, Domier LL. Family Luteoviridae. In: Fauquet CM, Mayo MA, Maniloff J, Desselberger U, Ball LA, editors. Virus taxonomy: VIIIth report of the ICTV. London: Academic Press; 2005. p. 891-900.

DeBlasio SL, Xu Y, Johnson RS, Rebelo AR, MacCoss MJ, Gray SM, et al. The interaction dynamics of two potato leafroll virus movement proteins affects their localization to the outer membranes of mitochondria and plastids. Viruses. 2018;10:585.

Gholamalizadeh R, Vahdat A, Keshavarz T, Elahinia A, Bananej K. Occurrence and distribution of ten viruses infecting cucurbit plants in guilan province, Iran. Acta Virol. 2008;52:113-8.
Guilley H, Wipf-Scheibel C, Richards K, Lecoq H, Jonard G. Nucleotide sequence of cucurbit aphid-borne yellows luteovirus. Virology. 1994;202:1012-7.

Han YH, Xiang HY, Wang Q, Li YY, Wu WQ, Han CG, et al. Ring structure amino acids affect the suppressor activity of melon aphid-borne yellows virus P0 protein. Virology. 2010;406:21-7.

He C, Molen TA, Xiong X, Boiteau G, Nie X. Cytochrome c oxidase mRNA as an internal control for detection of potato virus $Y$ and potato leafroll virus from single aphids by a co-amplification RT-PCR assay. J Virol Methods. 2006;138: 152-9.

Hipper C, Brault V, Ziegler-Graff V, Revers F. Viral and cellular factors involved in phloem transport of plant viruses. Front Plant Sci. 2013;4:154.

Hipper C, Monsion B, Bortolamiol-Becet D, Ziegler-Graff V, Brault V. Formation of virions is strictly required for turnip yellows virus long-distance movement in plants. J Gen Virol. 2014;95(2):496-505.

Hogenhout SA, Ammar ED, Whitfield AE, Redinbaugh MG. Insect vector interactions with persistently transmitted viruses. Annu Rev Phytopathol. 2008:46:327-59.

Holsters M, de Waele D, Depicker A, Messens E, van Montagu M, Schell J. Transfection and transformation of Agrobacterium tumefaciens. Mol Gen Genet. 1978;163:181-7.

Hu RJ, Zhao TY, Zuo DP, Wang Y, Zhang ZY, Han CG. Antiserum preparation of the movement protein of barley yellow dwarf virus PAV Qinghai isolate and its serological relationships with other BYDVs. Acta Phytopathol Sin. 2020; 50(2):141-6 (in Chinese). https://doi.org/10.13926/j.cnki.apps.000463.

Juarez M, Truniger V, Aranda MA. First report of cucurbit aphid-borne yellows virus in Spain. Plant Dis. 2004;88:907.

Knierim D, Deng TC, Tsai WS, Green SK, Kenyon L. Molecular identification of three distinct polerovirus species and a recombinant cucurbit aphid-borne yellows virus strain infecting cucurbit crops in Taiwan. Plant Pathol. 2010;59: 991-1002.

Knierim D, Maiss E, Kenyon L, Winter S, Menzel W. First full-length genome sequence of the polerovirus luffa aphid-borne yellows virus (LABYV) reveals the presence of at least two consensus sequences in an isolate from Thailand. Arch Virol. 2015;160:2633-6.

Knierim D, Tsai WS, Maiss E, Kenyon L. Molecular diversity of poleroviruses infecting cucurbit crops in four countries reveals the presence of members of six distinct species. Arch Virol. 2014;159:1459-65.

Lecoq H, Bourdin D, Wipe-scheibel C, Bon M, Lot H, Lemaire O, et al. A new yellowing disease of cucurbits caused by a luteovirus, cucurbit aphid-borne yellows virus. Plant Pathol. 1992;41:749-61.

Lee L, Kaplan IB, Ripoll DR, Liang D, Palukaitis P, Gray SM. A surface loop of the potato leafroll virus coat protein is involved in virion assembly, systemic movement, and aphid transmission. J Virol. 2005;79:1207-14.

Lee L, Palukaitis P, Gray SM. Host-dependent requirement for the potato leafroll virus 17-kDa protein in virus movement. Mol Plant-Microbe Interact. 2002;15: 1086-94.

Lemaire OJ, Gubler WD, Valencia J, Lecoq H, Falk BW. First report of cucurbit aphid-borne yellows Luteovirus in the United States. Plant Dis. 1993;77:1169.

Li YY, Sun Q, Zhao TY, Xiang HY, Zhang XY, Wu ZY, et al. Interaction between brassica yellows virus silencing suppressor P0 and plant SKP1 facilitates stability of PO in vivo against degradation by proteasome and autophagy pathways. New Phytol. 2019;222:1458-73.

Liu Y, Li F, Li YY, Zhang SB, Gao XW, et al. Identification, distribution and occurrence of viruses in the main vegetables of China. Sci Agric Sin. 2019;52: 239-61. (in Chinese). https://doi.org/10.3864/j.issn.0578-1752.2019.02.005.

Maina S, Edwards OR, de Almeida L, Ximenes A, Jones RAC. First complete genome sequence of suakwa aphid-borne yellows virus from East Timor. Genome Announce. 2016;4:e00718-6.

Mnari Hattab M, Kummert J, Roussel S, Ezzaier K, Zouba A, Jijakli MH. First report of cucurbit aphid-borne yellows virus in Tunisia causing yellows on five cucurbitaceous species. Plant Dis. 2005;89:776.

Orfanidou C, Maliogka VI, Katis NI. First report of cucurbit chlorotic yellows virus in cucumber, melon, and watermelon in Greece. Plant Dis. 2014;98:1446-7.

Peng B, Kang BS, Wu HJ, Liu LF, Liu LM, Fei ZJ, et al. Detection and genome characterization of a novel member of the genus polerovirus from zucchini (Cucurbita pepo) in China. Arch Virol. 2019;164:2187-91.

Peter KA, Gildow F, Palukaitis P, Gray SM. The C terminus of the polerovirus P5 readthrough domain limits virus infection to the phloem. J Virol. 2009;83: 5419-29.

Prufer D, Kawchuk LM, Rohde W. Polerovirus ORF0 genes induce a host-specific response resembling viral infection. Can J Plant Pathol. 2006;28:302-9. 
Prufer D, Wipf-Scheibel C, Richards K, Guilley H, Lecoq H, Jonard G. Synthesis of a full-length infectious cDNA clone of cucurbit aphid-borne yellows virus and its use in gene exchange experiments with structural proteins from other luteoviruses. Virology. 1995;214:150-8.

Rashid MO, Zhang XY, Wang Y, Li DW, Yu JL, Han CG. The three essential motifs in PO for suppression of RNA silencing activity of potato leafroll virus are required for virus systemic infection. Viruses. 2019;11:170.

Shang QX, Xiang HY, Han CG, Li DW, Yu JL. Distribution and molecular diversity of three cucurbit-infecting poleroviruses in China. Virus Res. 2009;145:341-6.

Shang QX, Xiang HY, Li DW, Yu JL, Han CG. Rapid detection and differentiation of three cucurbit-infecting poleroviruses by multiplex RT-PCR. J Agric Sci. 2012; 4:209-16

Smirnova E, Firth AE, Miller WA, Scheidecker D, Brault V, Reinbold C, et al. Discovery of a small non-AUG-initiated ORF in poleroviruses and luteoviruses that is required for long-distance movement. PLoS Pathog. 2015;11(5): e1004868.

Sokolova M, Prufer D, Tacke E, Rohde W. The potato leafroll virus $17 \mathrm{kDa}$ movement protein is phosphorylated by a membrane-associated protein kinase from potato with biochemical features of protein kinase C. FEBS Lett. 1997:400:201-5.

Sun Q, Li YY, Wang Y, Zhao HH, Zhao TY, Zhang ZY, et al. Brassica yellows virus PO protein impairs the antiviral activity of NbRAF2 in Nicotiana benthamiana. J Exp Bot. 2018;69:3127-39.

Tomassoli L, Meneghini M. First report of cucurbit aphid-borne yellows virus in Italy. Plant Pathol. 2007;56:720.

Vidal AH, Sanches MM, Alves-Freitas DMT, Abreu EFM, Lacorte C, Pinheiro-Lima B, et al. First world report of cucurbit aphid-borne yellows virus infecting passionfruit. Plant Dis. 2018;102:2665.

Xiang HY. Molecular characterization of novel poleroviruses and poleroviral PO protein functional analysis. China Agricultural University PhD Dissertation 2011 (in Chinese).

Xiang HY, Shang QX, Han CG, Li DW, Yu JL. Complete sequence analysis reveals two distinct poleroviruses infecting cucurbits in China. Arch Virol. 2008a;153; 1155.

Xiang HY, Shang QX, Han CG, Li DW, Yu JL. First report on the occurrence of cucurbit aphid-borne yellows virus on nine cucurbitaceous species in China. Plant Pathol. 2008b:57:390

Xu Y, Da Silva WL, Qian Y, Gray SM. An aromatic amino acid and associated helix in the C-terminus of the potato leafroll virus minor capsid protein regulate systemic infection and symptom expression. PLoS Pathog. 2018;14(11): e1007451.

Yahaya A, Dangora DB, Alabi OJ, Zongoma AM, Kumar PL. Detection and diversity of maize yellow mosaic virus infecting maize in Nigeria. VirusDisease. 2019;30:538-44.

Yang F, Rashid MO, Zhang XY, Zhang ZY, Wang Y, Li DW, et al. Development of polyclonal antiserum against movement protein from potato leafroll virus and its application for the virus detection. Phytopathol Res. 2019;1:5.

Zhang SK, Zhao TY, Liu JT, Zi LY, Li XY, Wang Y, et al. First report of cucurbit aphid-borne yellows virus in passion fruit plants exhibiting mosaic and mottling in China. Plant Dis. 2019;104:601.

Zhang XY, Dong SW, Xiang HY, Chen XR, Li DW, Yu JL, et al. Development of three full-length infectious CDNA clones of distinct brassica yellows virus genotypes for agrobacterium-mediated inoculation. Virus Res. 2015;197:13-6.

Zhang XY, Zhao TY, Li YY, Xiang HY, Dong SW, Zhang ZY, et al. The conserved proline18 in the polerovirus P3a is important for brassica yellows virus systemic infection. Front Microbiol. 2018;9:613.

Zhuo T, Li YY, Xiang HY, Wu ZY, Wang XB, Wang Y, et al. Amino acid sequence motifs essential for P0-mediated suppression of RNA silencing in an isolate of potato leafroll virus from Inner Mongolia. Mol Plant-Microbe Interact. 2014;27: $515-27$.

Ziegler-Graff V, Brault V, Mutterer JD, Simionis MT, Herrbach E, Guilley H, et al. The coat protein of beet western yellows luteovirus is essential for systemic infection but the viral gene products P29 and P19 are dispensable for systemic infection and aphid transmission. Mol Plant-Microbe Interact. 1996; 9:501-10.

\section{Ready to submit your research? Choose BMC and benefit from:}

- fast, convenient online submission

- thorough peer review by experienced researchers in your field

- rapid publication on acceptance

- support for research data, including large and complex data types

- gold Open Access which fosters wider collaboration and increased citations

- maximum visibility for your research: over $100 \mathrm{M}$ website views per year

At BMC, research is always in progress.

Learn more biomedcentral.com/submissions 